\title{
Empowering Adult Learners through Blogging with iPads and iPods
}

\author{
Anna Augusto Rodrigues \\ University of Ontario Institute of Technology and Durham College
}

\begin{abstract}
Current statistics indicate that 48 per cent of Canadians over the age of 16 struggle with low literacy skills (Canadian Council on Learning, 2008). The federal government has deemed the development of digital literacy proficiencies amongst Canadians a national priority as this country moves toward a digital economy (Government of Canada, 2012). This research project examined whether adult learners with literacy challenges would feel empowered as a result of creating content for a blog through the use of digital technology. The researcher attempted to understand the impact that blogging and using different types of technology could have on an individual's self-esteem and whether those feelings of empowerment would encourage an adult learner to pursue further education. Although this research project only ran for a period of six days at a literacy program, there was a noticeable difference in how the participants viewed themselves after they created digital content. Further findings from this project also indicated that there is a gap in research dealing with the impact of digital technology on adult literacy.
\end{abstract}

Keywords: adult literacy, digital technology, iPads, blogging, empowerment

\section{Introduction}

Blogging became a light. It's like grabbing a torch and running. I didn't know the world is so bright. Study participant

This research paper explores the following question: Will adult learners with literacy challenges feel empowered as a result of creating content for a blog through the use of digital technology? In an attempt to understand these issues, a two-week workshop was conducted for six adult students who were participating in a literacy program at a social service agency. The six participants created blog posts using iPads, took images and video with iPods, and created digital narratives through the use of the editing software, iMovie, which was installed on a MacBook 
Pro laptop ${ }^{1}$.

Literacy, in its most basic sense, is defined as "the ability to understand and employ printed information in daily activities at home, at work and in the community - to achieve one's goals, and to develop one's knowledge and potential" (Statistics Canada, 2005, p.11). Human Resources and Skills Development Canada (HRSDC) measures adult literacy (which includes numeracy, document use, and problem solving) on a scale from Level 1 to Level 5, with Level 1 being the lowest level and Level 5 the highest (Human Resources and Skills Development Canada, 2012). These levels, adopted by HRSDC, were developed for the Adult Literacy and Life Skills Survey (ALL), which was an effort to assess the literacy skills of participants from seven different countries, including Canada (Statistics Canada, 2005). The descriptions for each level can be found at the following link on the Statistics Canada website http://www.statcan.gc.ca/pub/89-588-x/4152886-eng.htm-3. According to this adult literacy indicator, individuals need to attain a Level 3 to be able to navigate Canadian society successfully; however, the International Adult Literacy Skills Survey (IALSS) and the Canadian component of ALL, indicated that 12 million Canadians over the age of 16 were performing below Level 3 at the time the study took place (Statistics Canada, 2005).

The impact of low literacy on an individual's life is profound. Adults with lower levels of literacy will encounter difficulties obtaining and keeping long-term employment, and are more likely to live in a low-income household (Ontario Literacy Coalition ${ }^{2}$, 2009). Lower levels of literacy in a population also impact Canada as a nation. According to the 2008 report, Reading the Future: Planning to meet Canada's future literacy needs, low literacy in the population means "our country is limited in its ability to access skilled workers needed to support economic growth and a strong society" (Canadian Council on Learning, 2008, p. 8).

The definition of what it means to be literate has changed rapidly in the past few years, particularly when associated with skills required in a contemporary workforce. Today's digital economy asks employees to have many skills beyond reading, writing, and arithmetic, as a $21^{\text {st }}$ century workforce must also be comfortable learning and operating a wide range of digital technology, ranging from desktop computers to smaller mobile devices (Ministry of Training,

\footnotetext{
1 This project has been partially supported by a CFI/ORF Infrastructure Grant through the EILAB in the Faculty of Education at UOIT, in collaboration with the Inclusive Design Institute. I would like to acknowledge the support of Dr. François Desjardins, at the Faculty of Education at UOIT, through whom I was able to borrow sufficient hardware for all the participants in my study.

2 Essential Skills Ontario (ESO) was formerly known as the Ontario Literacy Coalition. Some of the reports and papers from the ESO still reflect their former name, such as the one referenced in this paper.
} 
Colleges and Universities, 2011).

There are many factors deterring adults from upgrading their literacy skills, such as the level of funding provided by the government to support literacy programs and the economic situations of those requiring help (Maxwell \& Teplova, 2007). There is, however, a less noticeable barrier that manifests itself often in adult education: the lack of confidence in one's ability to learn. Adkins and Ozanne (2005) stated that adults with low literacy feel stigmatized, as they hold the belief that society perceives them as failing to meet pre-determined societal standards. The way adults feel about their ability to learn can hinder or even put an end to goals to improve their literacy skills. Research has shown that having a positive academic identity can boost an adult learner's self-esteem and encourage a student to further his or her education (Terry, 2005).

\section{Literature Review}

A literature review was conducted in an attempt to understand the place of this research amongst studies already completed. A most notable gap was found in the use of digital technology in adult literacy classes, although there are studies researching the efficacy of tablet computers in other educational settings in addition to articles on the integration of iPods and other types of portable players at the post-secondary level. The literature review is divided into four parts, each focusing on key issues related to the study's research question: Empowerment through literacy, Multiliteracies, Use of blogs in adult education, and Role of digital technologies in adult literacy.

\section{Empowerment through literacy}

Literacy skills are essential to the financial health of a nation and to the economic security of an individual (Maxwell \& Teplova, 2007), but there is also another dimension to the importance of enhancing one's literacy skills, including the sense that one is entitled to participate in literate cultures and to have a voice in public discourse, which Peirce (1995) describes as "an awareness

of the right to speak" (p. 18). For many adult learners, that individual satisfaction transforms into a desire to continue on a journey of acquiring knowledge while inspiring others to reach for the same goal, thus disrupting the status quo (Freire, 1999). This could be defined as emancipatory literacy, a concept forwarded by Freire and Macedo (1987), suggesting students should not only learn how to read, but also become aware of their histories to understand and 
question their roles in society. Furthermore, this concept promotes recognizing how dominant powers control the subjugated so that the oppressed can escape from their own surroundings (Kincheloe, 2005). This theoretical framework, developed by Paulo Freire, is known as Critical Pedagogy, and is a theory rooted in the idea of social and educational equality for everyone in society. Critical Pedagogy also asserts that individuals become empowered and self-sufficient by taking charge of their education and, in essence, by learning how to be self-directed learners (Kincheloe, 2005). Freire (1999) states that when individuals learn to read and write, literacy can no longer be regarded as a neutral activity but rather one charged with political and social implications.

Harste (2003) asks, "What kind of lives do we want to live and what kind of people do we want to be?" (p.11). These are very important questions for individuals with low literacy skills to answer in the context of emancipatory literacy. As an individual begins to understand that he or she actually has the right to answer these questions, the first step toward empowerment has begun (Freire, 1999). The process leads to transformative learning, a theory that values learners' experiences, and encourages reflection and free thinking that leads to taking one's knowledge to a different level (Mezirow, 1997). Although transformative learning seems to be an individual pursuit, it actually does not take place in a vacuum, but rather, through socially constructed knowledge within groups where problem solving and collaboration occur (Mezirow, 1997; Cranton \& King, 2003).

\section{Multiliteracies}

Papen (2005) suggests that the traditional definition of literacy as an ability to understand the written word, disregards the idea of other literacies. The boundaries of what it means to be literate have increased, and within these newly formed contexts, multimodality - described as text employing a variety of ways to communicate - plays an important role in that expansion (Rosewell \& Burke, 2009). Harste (2003), points out the importance of acknowledging multiple literacies, or multiliteracies, and their potential for allowing students to use and critically assess information which will allow them to think about issues in a meaningful manner, resulting in "thoughtful new social action" (p.11).

The notion of multiliteracies was advanced by New London Group (1996), who suggest that the word "literacy" needs to expand from the narrow description centering on "traditional 
language-based approaches" (p.1) to a definition that would account for not only the different ways people communicate, but also the diverse socio-cultural perspectives embedded in those communications. Many literacy practices are now recognized because the definition of the term "literacy" has evolved to include more than just written words in books. Consequently, the exclusivity of literacy has evaporated as even those who cannot read may still participate in meaningful discourse by being able to code and decode languages through street art, photography, video stories, etc. (DaSilva Iddings, McCafferty, \& Teixeira da Silva, 2011; MacGillivray \& Curwen, 2007).

\section{The use of blogs in adult education}

The activity of blogging has been identified as having the potential to teach $21^{\text {st }}$ century literacy skills (Johnson, 2010). According to Johnson (2010), "Blogs promote critical and analytical thinking and allow students to create content in ways not possible in traditional paper-and-pencil environments" (p.179). This is made possible due to blogging's online, digital nature. Blogs allow for not only written material to be posted but also video and audio content. Being online facilitates the process of sharing information, allowing communities surrounding a blog subject to be formed easily.

Griffith and Woong (2010) conducted a study in Australia that involved asking disadvantaged young adults, who were attempting to enter university, to use blogs in an English literature course. Simultaneously, Griffith and Woong (2010) conducted a similar study, but with students already attending university. The two groups were able to connect with each other, through their blogs, over the course of the study. Griffith and Woong (2010) found that underprivileged students, after some initial difficulties, enjoyed the blogging process and were able to enhance their literacy skills as they used the blogs to express their thoughts by publishing their own poetry and essays. As a result, some of the participants were accepted into university, but the researchers also pointed to the difference in how the students felt about themselves before and after they had started blogging. Some of the students were homeless, and dealing with addiction issues. Some felt it would be difficult to get into university because of their backgrounds, but the blogging experience boosted their confidence as their written projects received positive feedback from students already attending university and the general public (Griffith \& Woong, 2010).

Park, Heo, and Lee (2011), researched how blogs could be used in informal adult learning and 
found several interesting outcomes with respect to the impact of blogging on the 70 adults who participated in their study. In this case, the researchers demonstrated that blogging was an informal learning practice that enriched the lives of the participants, the majority of whom reported positive learning experiences while blogging (Park, Heo, \& Lee, 2011).

Blogs have also been used in English as a Second Language (ESL) classes with adult learners with good results; however, with that type of learner, researchers have found there are certain factors that must be considered. Sheetz and Curcher (2008) experimented with blogging in two courses being taught at a college in the United Arab Emirates (UAE). One of the first issues the researchers ran into was the fact that, although the students were adults, many didn't show the characteristics associated with adult learners as described in Andragogy learning theory. Andragogy is a theory in Adult Education developed by American educator Malcolm Knowles, which includes several assumptions about adult learning, including that adult students prefer to learn in individualized settings without much direction or guidance from teachers (Knowles, Holton, \& Swanson, 2005).

Sheetz and Curcher (2008) felt the adult students were not self-directed nor were they interested in discovering things on their own. These learners were relying on their teachers to direct their learning and were not comfortable acting on their own (Sheetz \& Curcher, 2008). The researchers had introduced the blogs into a first-year classroom and a fourth-year classroom and, although they reported similar results from both groups of students, they felt that, regardless of the year the student was in, the learning needed to be scaffolded. In other words, the student learning was done in increments; easier tasks were introduced first and only when these were mastered would the students move on to a slightly more difficult assignment. The facilitators found that students required support on an on-going basis until they were comfortable to blog on their own. Furthermore, the type of scaffolding needed to be changed during the process. This seems to indicate that when blogging is introduced as an activity to enhance the literacy skills of adult learners, the plan to do this needs to be flexible, and their cultural backgrounds needs to be considered (Sheetz \& Curcher, 2008).

\section{Digital technology in adult education}

Manuguerra and Petocz (2011) reported on the use of iPads to promote student engagement at the post-secondary level. Their study, which covered a period of 15 months, found that student 
engagement increased in classrooms and outside of classrooms with the use of iPads. An example of that increased engagement can be found in how lectures in the classroom changed when the iPad was used to deliver them. Manuguerra and Petocz (2011) found that static slides were switched to more lively presentations with the ability for the slides to be annotated on the iPad itself. The presentations were also recorded, allowing students to access them at a later date. When the authors conducted an anonymous survey to measure the value of running the lectures with an iPad, all of the students who responded expressed no interest in returning to a traditional form of lecturing in the classroom (Manuguerra \& Petocz, 2011).

Students are more engaged in classroom learning when using a digital tablet, and teachers have noticed that schoolwork, although more spontaneous, is more creative (Roschelle et al., 2007). As well, there is recognition that this new technology favours "constructivist and collaborative approaches to learning, and flexible and adaptive approaches to teaching" (Manuguerra \& Petocz, 2011, p.61). These findings align easily with the mission statements of most, if not all, literacy programs.

\section{Theoretical Framework}

Empowerment through the gain of knowledge was a constant theme within the current project's diverse facets, including using different types of technology to create a variety of texts. This approach aligns well within a framework that positions literacy as social practice, which sees a wholehearted acceptance of literacy's power to transform an individual's life for the better (Freire, 1999). Participants in the current study were asked to see themselves as creators of texts instead of merely being passive consumers. By putting their work online for others to read and comment on, they were also changing their history with literacy from one-way communication to something more dynamic. As such, a shift in the participants' relationships with their educational selves needed to occur so that an acceptance of one's power to transform and flourish could be acknowledged. The students needed to embrace a "language of possibility" (Giroux, 2001, p.81) without any hesitation, which would further propel them on paths to educational success. Literacy as social practice is a great proponent of that concept.

Participants in this research project were also asked to express themselves in a variety of ways, such as creating computer-mediated texts, recording video, and taking photos. Those skills were viewed through a lens firmly entrenched in literateness instead of learning basic day-to-day 
proficiencies not always associated with literacy (Wilson, 2009). Through this process, the students' own narrow definitions of what it means to be literate expanded to include more than just written text and numeracy.

\section{Research Methodology}

This study used a qualitative approach - a method chosen due to its application in specific settings - which allows a researcher to focus on understanding the happenings he or she is observing and documenting (Golafshani, 2003). The nature of qualitative research, composed in a straightforward and casual manner with "detailed, rich and thick descriptions" (Johnson \& Onwuegbuzie, 2004, p. 14), also aligned with the issue being researched, which is deeply rooted in social equity and education. This project asked participants to reflect on their educational journeys, what had brought them to the basic education program they were attending, and their thoughts on digital technology. Using a semi-structured interview method, participants were required to reflect on their past life experiences and future aspirations, revealing through conversations their disappointments, dreams, fears and moments of pride.

The research methodology adopted in the collection of data was action research. Action research has been described as an approach to resolve real-world problems rooted in inequality and discrimination (Adelman, 1993; Bogdan \& Biklen, 2003). Described as a practical tool, action research tries to find answers for problems, such as low literacy, that individuals face on a daily basis but that sometimes do not present themselves easily and go unnoticed (Hansen \& Brady, 2011; Bogdan \& Biklen, 2003). As the word "action" implies, this is not armchair research but rather an exploration that takes place where the issue is occurring, allowing researchers to document firsthand what they are seeing and hearing (O’Brien, 2001).

In this project, four specific methods, within the methodologies chosen, were used: semistructured interviews, focus groups, participant observation and visual analysis. Interviewing participants to collect data was an appropriate research method due to the subject matter being discussed, which involved probing participants on their educational challenges - a difficult topic to discuss, especially with someone you are not well acquainted with. Elmir, Schmied, Jackson, and Wilkes (2011) suggest that interviewing participants, face-to-face, makes discussing difficult topics easier as the two people talking can build a rapport, and the conversation becomes twoway communication. Conducting a post-workshop focus group was important to this project due 
to the inherent collaborative nature of this data collection technique (Hoskyns, 2011). Described as a method to draw out information by allowing participants to respond to comments another person in the group has made (Kitzinger, 1994), this research method emphasizes allowing group dynamics to dictate where the conversation will go.

Another research method employed was participant observation, a method in which "the researcher is playing an established participant role in the scene studied" (Atkinson \& Hammersley, 1998, p.2). This data collection method is in line with the parts that the researcher played in this research project, being both instructor and investigator. Liebow (1993) describes participant observation as a method in which researchers embed themselves into the situation they are studying by sharing, as much as possible, in the lives of the research participants, and simultaneously trying to "see the world from their perspective" (p. 7). Although there are pitfalls to conducting research using this method - such as the researcher getting too close to the participants and not being able to analyze the data objectively (Atkinson \& Hammersley, 1998) - participant observation allows the researcher an opportunity to forge deeper connections with the participants that will lead to a trusting relationship between the two. This trust will permit for the collection of richer data that are more profound and purer in a sense (Liebow, 1993).

In recent years, the visual analysis of artifacts as an examination method has become increasingly common in research (Knoblauch, Baer, Laurier, Petschke, \& Schnettler, 2008). Adler and Clark (2011) argue that still images and videos should be treated as data as they offer a different viewpoint from that of traditional information collection, such as interviews. Participants in the current research project created digital narratives with still images and video they had recorded. These artifacts were analyzed using the same codes in place for analyzing data collected from interviews and field notes.

\section{Research Design and Data Analysis}

The participants for this project were recruited from a social service agency located in Durham Region. This particular agency, which has a variety of chapters across Canada, is a non-profit organization with services such as basic education for adults, harm reduction programs, and parenting skills. The Durham Region chapter runs a basic literacy skills program to help adults upgrade their education. Some of the program's clients are working toward their high school diplomas while others are progressing with the intention of entering academic upgrading 
programs at community colleges. The program accepts participants on a continuous basis and the instruction is individualized. A client, upon entry into the program, has her or his literacy skills assessed, and then a customized educational plan is established with the help of an instructor. Some clients stay in the program for months while others stay for only weeks. During that time, the instructors, who are working one-on-one with the students, learn much about students' aptitudes, learning styles and long-term goals. Based on this information, it was only logical that the instructors from the basic literacy program at the social service agency recruit the participants for this project.

In the recruitment process, the instructors approached students who were between Levels 2 and 3 on the HRSDC literacy indicator, and who had little or no experience using digital technology, but showed openness to learning more about it. Once the participants were identified, the first interviews were conducted with each. The main topics of the first interview were participants' educational histories, their thoughts on digital technology, and their short and long-term educational goals. The second interview with each participant took place after the workshop, and they were asked the same questions except for the question regarding educational background. During the focus group meeting, which took place after the workshop, students were asked for their thoughts on what they had learned in the workshop.

On the first day of the workshop, participants were told they would be learning how to create digital content for a blog using iPads. Students learned how to operate an iPad, including how to open and close applications; how to write content for a blog using the Wordpress app (a blogging application that can be used on an iPad); and how to publish their written pieces (posts) to a blog created specifically for the workshop. Students also learned, on another day, how to take images and video with iPods, and learn how to edit the images and video together to create digital narratives with text and music. The students created and posted content to the following blog: http://jhsreflections.wordpress.com. The method of having students post content to one blog, instead of having them each create their own, was chosen as a way to foster a sense of community among the participants.

New literacies, such as blogging, have been identified as an online abode where collaborative efforts take place in "participatory practice" (Merchant, 2009, p.111), allowing contributors to construct knowledge collectively. Wenger's (1998) Communities of Practice $(\mathrm{CoP})$ theory suggests that learning happens within a group setting through the exchange of ideas 
between members. This theory fits well with the type of blogging activity the participants of this research project were involved in because it was a small group of people who were building their knowledge collectively by sharing the work they created individually in a communal area - the blog.

Data was collected from interviews, observation of participants, and by analyzing artifacts produced during the workshop. The data included: text-based blog posts, blog posts that were images and videos; responses and replies to blog posts; pre- and post-project interview transcripts and field notes. Transcripts from the interviews and focus group, field notes, and the digital narratives were all coded using a grounded theory approach - a method which develops ideas inductively from the existent data (Adler \& Clark, 2011). According to Jones, Kriflik, and Zanko (2005), grounded theory can be described as "data collection, coding and analysis occurring immediately, concurrently, and throughout" (p. 6). Larger themes pertaining to the initial research question were identified and categorized into eight areas in the open data analysis. Selective coding was then used to create the emergent storyline (Borgatti, 2005). Selective coding entailed formulating a main concept, which became the main category to which a number of sub-categories were connected (LaRossa, 2005). Based on the themes identified in the transcriptions and notes, the predominant narrative in this research project revolved around transformation of self in a social context.

\section{Discussion of Findings}

The findings from this research project show that although blogging was a new concept to the participants, they enjoyed doing it and felt empowered throughout the process. One participant commented how blogging made him realize that he could write his thoughts with confidence. Another stated that the fear of not understanding what the word "blog" meant had disappeared and had opened up her mind to new learning:

What a new world I've been exposed to. It's been a wonderful experience. The knowledge, the confidence now... it's not a foreign word anymore because to be honest, blogging, Twitter, what's that all about it? You know, you are watching TV, you are watching the news and it is like you hear the word blog and you think, "what is this new thing about"? So when you mentioned blogging I thought, "Should I get involved? What if I look silly?" It has been a great experience. 
Several of the participants commented that they preferred writing their thoughts using an iPad rather than a pencil, or using one of the desktop computers available at the agency. One participant said that he liked using the iPad to type as he did not feel under pressure to use all his fingers when typing, something he does not usually do. Therefore, using the iPad allowed this student to focus exclusively on writing. Another participant stated that using the iPad allowed the ideas to flow more easily and allowed her writing to have fewer mistakes:

When people want stories from me, the paper will be there but it will be empty for days because in my mind I want to say it but don't know how to get it on the paper, how to start it. But with the iPad, I just kept going and I was shocked with how much I got done. I don't know in two hours, or one hour. When I wrote that, a lot came off. I wouldn't have written it on paper. But my fingers kept going. I was concentrating on that and I blocked everything out.

Learning how to use the iPod, and subsequently using the device to create movies and capture still images, seemed to elicit the same feelings brought on by learning how to blog using the iPad. During a trip to a park, participants were asked to take images and to record video of anything they wished for the purpose of creating a digital narrative. During that time, the participants discussed and made choices about the footage and images they were taking. One participant decided that she would create a digital narrative consisting of shadows and peculiar tree and flower formations. This participant then directed some of the people around her, including the researcher, to stand in certain ways so she would be able to take images of our shadows (Figure 1). 


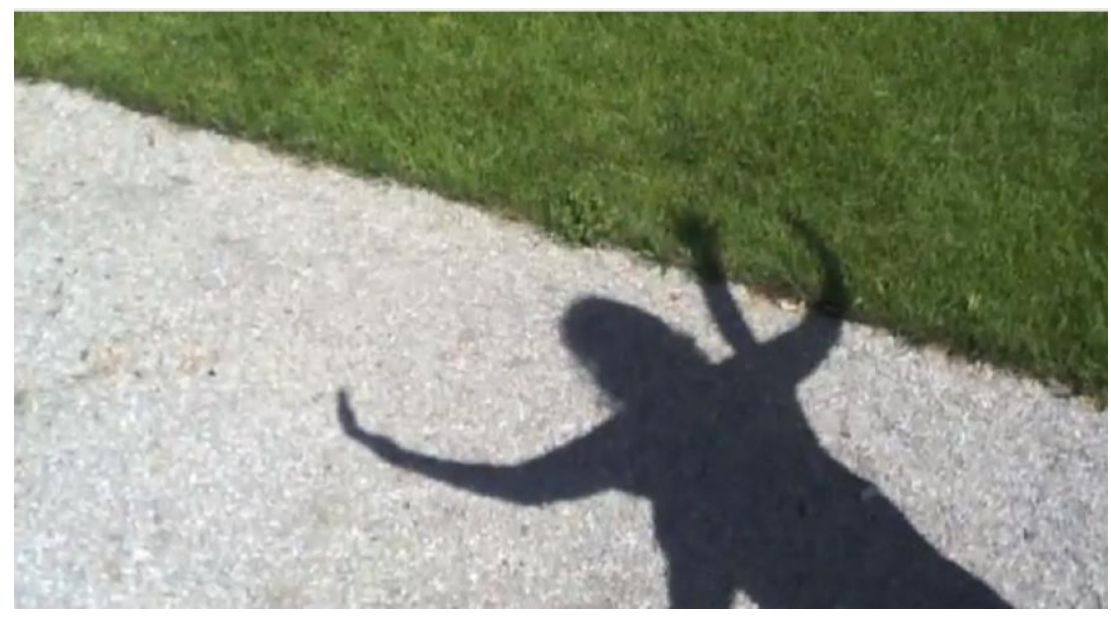

Figure 1. A photograph taken by Shabba (pseudonym), a workshop participant.

The complete narrative is available at: http://www.youtube.com/watch?v=LLwe4JqIwh0

During the field trip to the park, two of the participants branched off and worked on their own; however, the other four stayed together providing each other with encouragement, troubleshooting support and creative ideas. It was revealed in the focus group and second interviews that many of the participants enjoyed this part of the workshop mostly because they were introduced to something they had never experienced before. One participant commented on how much he enjoyed taking images and video with the iPod, and another stated that learning this process had made her think about job opportunities in the field of video production.

A visual analysis of some of the images and video taken during the trip to the park indicates an assuredness with the technology and an understanding of what it can do. One participant took many close-ups of flowers (Figure 2) and the participant who had earlier experimented with shadows worked with her surroundings to create a natural collage using a reflection and a face (Figure 3). 


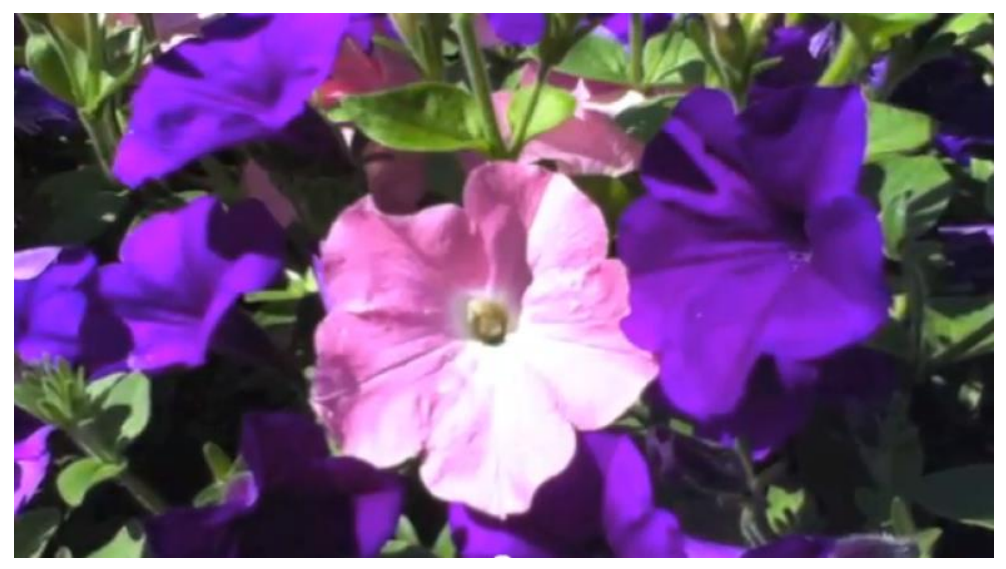

Figure 2. A photograph taken by Richard, a workshop participant.

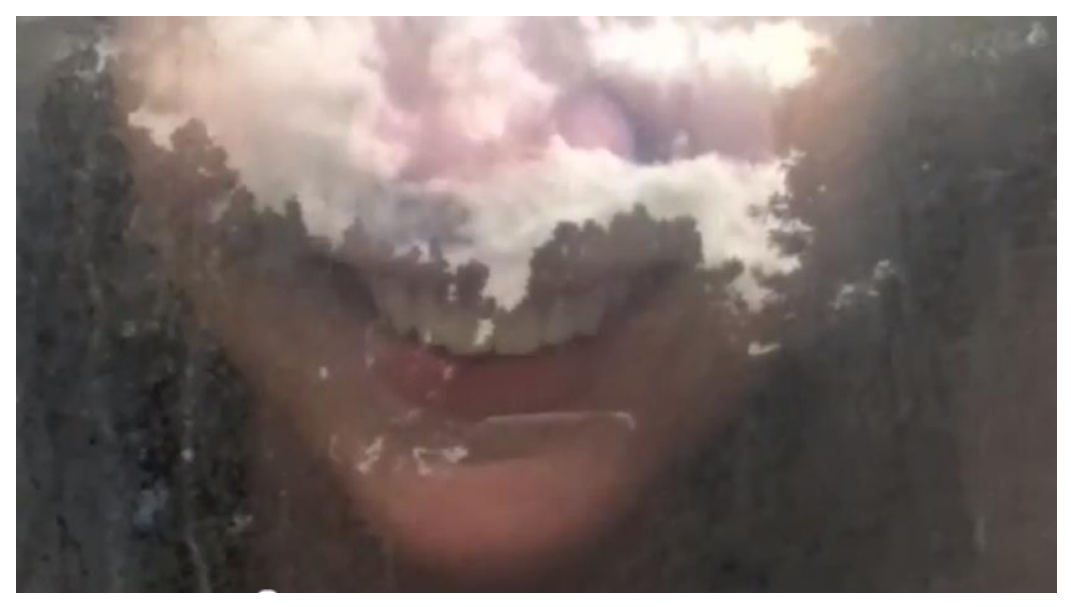

Figure 3. Another photograph taken by Shabba, a workshop participant. 
The participants in this study were given two days to edit their footage and still images into digital narratives. Learning how to edit with the iMovie application became an individual activity as each participant learned the functions of iMovie in a 15-minute overview. iMovie is editing software, found on Mac computers that is consumer-oriented, yet has many high-end features found in professional editing programs (Curtis, 2006). iMovie's fluid and intuitive interface makes it easy to learn the basics in 15 minutes. Music, text and transitions are all integrated within iMovie, permitting the novice editor to create videos with music and text efficiently. Once participants indicated that their digital narratives were complete, I uploaded the files to a YouTube channel used in my own teaching practice. From there, the YouTube embed code from the video was copied and then pasted into a post on the Reflections blog.

Some of the observations made while the participants were editing their narratives included the great care each took when choosing the music, the quality of the text being added to the videos, and the way the clips and photos were being placed on the timeline. ${ }^{3}$ One of the participants, who had enjoyed this part of the workshop more when compared to the blogging portion, also commented that the photography and video taking had made him feel like he developed something because he had the proof in the form of a finished narrative that he could show to his family and friends.

Research has shown a strong link between academic achievement and a learner's selfesteem (Golden, 2003; Janssen, 2004; Cox, 2007; Griffith \& Woong, 2010). The findings in this research project indicated that the participants felt that the knowledge they acquired had empowered them. As well, some of them indicated that this new information was impacting their educational goals. As mentioned earlier, adult literacy has been under-addressed in academia and that has led to the neglect of a substantial community of individuals who should be involved in the public sphere but are not adding their voices for a variety of reasons, including the fear of not having anything valuable to contribute to the discourse.

A review of the literature revealed a conspicuous gap in research dedicated to understanding the impact of digital technology on adult literacy; however, the use of digital technology in other learning situations - from elementary to post-secondary - has been well

\footnotetext{
${ }^{3} \mathrm{~A}$ timeline in editing is an area of the editing program where the video clips or photos in a media project will appear in the intended sequence the editor wishes the final product to appear in (apple.com, 2012).
} 
documented. The paucity of studies dealing with the use of digital technology in adult literacy classes is part of a larger problem described in a recent report as "a dearth of research on the use of digital media in adult literacy programs" (Greig \& Hughes, 2012, p. 3).

This project's findings showed the value of integrating technology in adult literacy programming for two important reasons. Learning how to operate these devices competently, "just like everyone else" - as one participant stated - boosted the users' self-esteem, and subsequently, also boosted their feelings of empowerment, allowing them to engage in even more complicated tasks as the workshop progressed. The second reason can be found in how this type of training aligns well with the federal government's digital economy strategy, which highlights the importance of using digital technology so that Canada can be competitive on a global level (Government of Canada, 2012). The findings from this project indicate that this gap in research on the impact of technology on adult literacy should be addressed more fully.

After the workshop concluded, the participants exhibited signs of having changed perspective on a variety of fronts, including how they felt about technology and their educational goals, and how they saw themselves as students and facilitators of knowledge. Changing perspective is a cornerstone of transformative learning (Mezirow, 1997) and the analysis of data revealed a telling storyline involving the change of perspective the participants underwent that was enabled by the social context in which these happenings took place. Wenger (1998) describes how communities of practice transform into communities of action where ideas are shaped through the collaboration of the members of the group. The group of participants taking part in this research project formed an alliance, albeit most likely not consciously, resulting in a community of practice where risks could be taken without fear and where learning happened without impediments such as lack of confidence. This situation helped foster feelings of empowerment that rippled through the group as they were faced with learning how to blog and how to operate digital technology that was unfamiliar.

\section{Limitations}

There were various limitations to this research project. The principal investigator acted both as researcher and workshop facilitator, and thus was unable to provide undivided attention to either role. As Cohen (2000) notes, this approach can cause problems as it erodes neutrality and can lead to the researcher's role being re-defined and misinterpreted by the participants. However, it 
is important to note that this method also allows researchers to use different, albeit personal, lenses for analyzing the data they are gathering (Claster \& Schwartz, 1972). By integrating into the group and interacting directly with participants, the researcher was able to collect richer data. Being at the same table where participants were writing and editing allowed the researcher to observe the small nuances that an observer from afar may not have noticed. As well, as everyone became more comfortable as a group, group members spoke in more familiar tones, leading to unfiltered comments and discussion.

Another limitation can be found in the sample used for this research. Only six participants attended all of the six days that the workshop ran, which resulted in a limited quantity of posts to the blog and digital narratives that consequently restricted the amount of data available for collection and analysis. As well, the short time in which the workshop ran did not allow for the development of a deeper understanding of the participants' perspectives on the skills they were learning and the technology they were operating. Also, only one official field trip was organized, and having all the participants use the same area to obtain images and video resulted in homogenous digital narratives. A more comprehensive understanding of the issues being addressed may more likely have been obtained through a longer and more sustained integration of the workshop within the basic adult education program at the Durham Region agency at which this study was conducted.

\section{References}

Adelman, C. (1993). Kurt Lewin and the Origins of Action Research. Educational Action Research, 1(1), 7-24.

Adler, E., \& Clark, R. (2011). An Invitation to Social Research: How It's Done (4th Ed.). Belmont, CA: Thomson/Wadsworth Publishing Co.

Adkins, N.R., \& Ozanne. J. L. (2005). Critical Consumer Education: Empowering the LowLiterate Consumer. Journal of Macromarketing, 25(2), 153-162.

Atkinson, P., \& Hammersley, M. (1994). Ethnography and participant observation. Handbook of qualitative research, 1, 248-261.

Bogdan, R.C., \& Biklen, S.K. (2003). Qualitative Research for Education ( $4^{\text {th }}$ ed.). Boston: Pearson. 
Borgatti, S. (2005). Introduction to Grounded Theory. Retrieved from: http://www.analytictech.com/mb870/introtoGT.htm

Canadian Council on Learning. (2008). Reading the Future: Planning to meet Canada's future literacy needs. Ottawa: Canadian Council on Learning.

Claster, D.S., \& Schwartz, H. (1972). Strategies of Participation in Participant Observation. Sociological Methods \& Research, 1(1), 65-96.

Cohen, J.H. (2000). Problems in the Field: Participant Observation and the Assumption of Neutrality. Field Methods, 12(4), 316-333.

Cox, T. D. (2007). Transformational Learning and the AAACE Conference. Adult Learning, $18(1 / 2), 18$.

Cranton, P., \& King, K.P. (2003). Transformative Learning as a Professional Development Goal. New Directions for Adult and Continuing Education, 98, 31-37

Curtis, M (2006). Review: iMovie '08. Retrieved from: http://www.macworld.com/article/1059668/imovie08.html

DaSilva Iddings, A. C., McCafferty, S. G., \& Teixeira da Silva, M. L. (2011). Conscientização through graffiti literacies in the streets of a São Paulo neighborhood: An ecosocial semiotic perspective. Reading Research Quarterly, 46(1), 5-21.

Dickerson, J., Williams, S., \& Browning, J. B. (2009). Scaffolding Equals Success in Teaching Tablet PCs. Technology Teacher, 68(5), 16-20.

Elmir, R., Schmied, V., Jackson, D., \& Wilkes, L. (2011). Interviewing people about potentially sensitive topics. Nurse Researcher, 19(1), 12-16.

Freire, P. (1999). Pedagogy of the Oppressed, 30th Anniversary edition. New York.

Freire, P. \& Macedo, D. (1987). Literacy: Reading the word and the world. Greenwood.

Giroux, H. A. (2001). Culture, power and transformation in the work of Paulo Freire. In F. Schultz (Ed.), SOURCES: Notable selections in education (3rd ed.) (pp. 77 - 86). New York: McGraw Hill Dushkin.

Golafshani, N. (2003). Understanding Reliability and Validity in Qualitative Research. The Qualitative Report, 8(4), 597-607.

Golden, S. (2003). Self-Efficacy: How Does It Influence Academic Success? Adult Learning, 14(3), 14-16. 
Government of Canada (2012). The Digital Economy in Canada. Retrieved from http://www.ic.gc.ca/eic/site/028.nsf/eng/Home

Greigg, C., \& Hughes, J. (2012). Adult Learners and Digital Media. AlphaPlus: Toronto.

Griffith, M., \& Woong, L. (2010). Empowering adult learners through blog - an Australian case study. Adult learning in the digital age: perspectives on online technologies and outcomes. United States of America: Information Science.

Hansen, R., \& Brady, E. (2011). Solving Problems Through Action Research. LLI Review, 682-90.

Harste, J.C. (2003). What do we mean by literacy now? Voices from the Middle, 10(3), 8-13.

Hoskyns, S. (2011). Collaborative conversations in focus group research: Music therapists reflect on combining research and practice. The New Zealand Journal of Music Therapy, 9, 32-60.

Human Resources and Skills Development Canada (2012). Indicators of well-being in Canada. Retrieved from: http://www4.hrsdc.gc.ca/.3ndic.1t.4r@-eng.jsp?iid=31

Janssen, O. (2004). The impact of learning. Adults Learning, 15(9), 24-26.

Johnson, B.R., \& Onwuegbuzie, A. J. (2004). Mixed Methods Research: A Research Paradigm Whose Time Has Come. Educational Researcher, 33(7), 14-26.

Johnson, D. (2010). Teaching with authors' blogs: connections, collaboration, creativity. Journal of Adolescent \& Adult Literacy, 54(3), 172-180.

Jones, M., Kriflik, G., \& Zanko, M. (2005). Grounded Theory: A theoretical and practical application in the Australian Film Industry. Retrieved from: http://ro.uow.edu.au/commpapers/46

Kidd, T. T., \& Keengwe, J. (2010). Adult learning in the digital age: Perspectives on online technologies and outcomes. United States of America: Information Science.

Kincheloe, J. (2005). Critical Pedagogy Primer. New York: Peter Lang Primer.

Kitzinger, J. (1994). The methodology of Focus Groups: the importance of interaction between research participants. Sociology of Health \& Illness, 16(1), 103-121.

Knoblauch, H., Baer, A., Laurier, E., Petschke, S., \& Schnettler, B. (2008). Visual Analysis: New Developments in the interpretative analysis of video and photography. Qualitative Social Research, 9(3), $14-17$. 
Knowles, M., Holton, E. F. III, \& Swanson, R. A. (2005). The adult learner: The definitive classic in adult education and human resource development (6th ed.). Burlington, MA: Elsevier.

LaRossa, R. (2005). Grounded theory methods and qualitative family research. Journal of Marriage and Family, 67(4), 837-857.

Liebow, E. (1993). Tell them who I am: the lives of homeless women. The Free Press: New York, New York.

Lohr, M. (2011). e-Learning using iPads. IEEE International Conference on Advanced Learning Technologies. DOI: 10.1109/ICALT.2011.75

MacGillivray, L., \& Curwen, M. (2007). Tagging as a social literacy practice. Journal of Adolescent \& Adult Literacy, 50(5), 354-369.

Manuguerra, M., \& Petocz, P. (2011). Promoting student engagement by integrating new technology into tertiary education: The role of the iPad. Asian Social Science, 7(11), 61-65.

Maxwell, J., \& Teplova, T. (2007). Social consequence of low language/literacy skills. Encyclopedia of Language and Literacy Development. Retrieved from: http://www.literacyencyclopedia.ca/pdfs/topic.php?topId=34

Merchant, G. (2009). Web 2.0, new literacies, and the idea of learning through participation. English Teaching: Practice and Critique, 8(3), 107-122.

Mezirow, J. (1997). Transformative learning: Theory to practice. New Directions for Adult \& Continuing Education, 74, 5-12.

Ministry of Training, Colleges and Universities. (2011). Literacy and Basic Skills. Retrieved From: http://www.tcu.gov.on.ca/eng/training/literacy/index.html

New London Group. (1996). A pedagogy of multiliteracies: Designing social futures. Harvard Educational Review, 66(1), 60-92.

O'Brien, R. (2001). Um exame da abordagem metodológica da pesquisa ação [An Overview of the Methodological Approach of Action Research]. In Roberto Richardson (Ed.), Teoria e Prática da Pesquisa Ação [Theory and Practice of Action Research]. João Pessoa, Brazil: Universidade Federal da Paraíba. (English version) Retrieved from: http://www.web.ca/ robrien/papers/arfinal.html

Ontario Literacy Coalition. (2009). Literacy in Ontario. Toronto: Ontario Literacy Coalition. Papen, U. (2005). Adult Literacy as Social Practice: More Than Skills. Florence: Routledge. 
Park, Y., Heo, G. M., \& Lee, R. (2011). Blogging for informal learning: Analyzing bloggers perceptions using learning perspective. Educational Technology \& Society, 14(2), 149-160.

Peirce, B. N. (1995). Social identity, investment, and language learning. TESOL Quarterly, 29(1), 9-31.

Roschelle, J., Tatar, D., Chaudhury, S. R., Dimitriadis, Y., Patton, C., \& DiGiano, C. (2007). Ink, improvisation, and interactive engagement: Learning with tablets. Computer, 40(9), 42.

Rosewell, J. \& Burke, A (2009). Reading by Design: Two case studies of digital reading practices. Journal of Adolescent \& Adult Literacy, 53(2), 106-118.

Sheetz, D., \& Curcher, M. (2008). Using blogs to enhance content learning for students who are learning in a second language. In C. Bonk et al. (Eds.), Proceedings of World Conference on E-Learning in Corporate, Government, Healthcare, and Higher Education 2008 (pp.1254-1259). Chesapeake, VA: AACE.

Statistics Canada. (2005). Building on our competencies: Canadian results of the International Adult Literacy and Skills Survey. Ottawa: Statistics Canada.

Terry, M. (2005). Making a difference in learners' lives: results of a study based on adult literacy programs. Adult Basic Education, 16 (1), 3-19.

Urbach, J. (2012). Beyond Story Grammar: Looking at stories through cultural lenses. Education \& Urban Society, 44(4), 392-411.

Wenger, E. (1998). Communities of Practice: Learning, Meaning, and Identity. Cambridge: Cambridge University Press.

Wilson, A. (2009). Literacy and Writing: Ideology in practice. Reviews in Anthropology, 38(4), 290-307.

Woyke, E. (2011) Tablets Attracting Repeat Buyers. Forbes.com. Retrieved from: http://www.forbes.com/sites/elizabethwoyke/2011/12/08/tablets-attracting-repeat-buyersunemployed-says-study/ 